\title{
Rationalization of Accounting (Financial) Statements of Land Assets in Agricultural Holdings of the Russian Federation
}

\author{
Bobovnikova T.Y.* \\ Russian State Agrarian University - Moscow Timiryazev \\ Agricultural Academy \\ Moscow, Russia \\ e-mail: bt32-1@bk.ru
}

\author{
Vorozheykina T.M. \\ The Financial University under the Government of the \\ Russian Federation \\ Moscow, Russia \\ e-mail: vorozheykina@gmail.com
}

\begin{abstract}
The article examines the current state of accounting (financial) statements as an integral part of the information base on land assets of organizations, as well as provides theoretical justification for improving the formation and use of reporting indicators of agricultural holdings. Studying data on the basis of information exchanged on the websites of companies reveals features of accounting and determines the main directions for its improvement. The methodological basis of the study was regulatory documents, information resources of agricultural holdings in the public domain. The reliability of the results of the article is based on the use of methods such as observation, comparison, generalization, and logical conclusions. The paper shows the analytical potential of the content of the information resource on land assets based on the statements of holdings. It is proved that "Land assets" should be shown as a separate article in the balance sheet for agricultural organizations, taking into account changes in quality indicators. The paper concludes that currently the formation of indicators of the accounting (financial) statements of agricultural organizations causes many problems. The structure and content of reporting by agricultural organizations is heterogeneous and closed for free access.
\end{abstract}

Keywords - accounting (financial) statements, land assets, agricultural holdings, Russian Federation, improvement, data openness

\section{INTRODUCTION}

In the conditions of the Central Black Earth Economic Region, the most common factor in changing the equilibrium (conservation, deterioration or improvement) of the natural environment is agriculture. The main agricultural activities are land resources. The development of effective land relations is impossible without accounting, accounting (financial) statements. Accounting (financial) statements must provide the information that is necessary for both external and internal users in matters of effective land tenure and land use. Agricultural lands, their use should be reflected in the accounting and financial reporting of not only agricultural holdings, but also enterprises.

\section{METHODS AND MATERIALS}

In this paper, using control procedures (methods and techniques), we analyzed various aspects of monitoring agricultural land based on data from organizations. As part of an integrated approach, we also used methods of observation, comparison, and generalization. The information base of the study was official sites, data of agricultural holdings of the Russian Federation, Kursk region.

\section{RESULTS}

According to the Federal State Statistics Service, for the third year a relatively stable dynamics of agricultural production has been observed - about 5.12 trillion rubles at actual prices annually. The area of agricultural land in Russia remains virtually unchanged $(51.6 \%$ or 197.8 million hectares). The main large agricultural landowners in the Russian Federation are presented in table 1.

TABLE I. $\quad$ LAND BANK LEADERS 2019 [1]

\begin{tabular}{|c|c|c|c|}
\hline \multirow{2}{*}{$\begin{array}{l}\text { Position } \\
\text { in } 2018\end{array}$} & \multirow[t]{2}{*}{ Company } & \multicolumn{2}{|c|}{ Land Bank, thousand ha } \\
\hline & & In 2017 & In 2018 \\
\hline 1 & Miratorg CYPRUS & 676 & 1000 \\
\hline 2 & "Prodimex + Agriculture" & 790 & 865 \\
\hline 3 & Rusagro CYPRUS & 675 & 650 \\
\hline 4 & Agrocomplex & 644 & 649 \\
\hline 5 & $\begin{array}{l}\text { EkoNiva-AIC - Stefan Duerr } \\
\text { (citizen of Russia since 2013) }\end{array}$ & 334 & 504 \\
\hline & Total & 3119 & 3668 \\
\hline
\end{tabular}

Rating leaders are building up a land bank. So, in one year, Miratorg increased your land assets by $48 \%$, and EkoNiva$\mathrm{AIC}-51 \%$.

As a rule, the owner takes care of the effectiveness of land use, and since the state has ceased to be a monopolist in this area in connection with the ongoing land reform. It has lost this function. We agree with Pechenkina V.V. that the state should take care and stimulate the conservation and increase of soil fertility. The current economic relations between the state, the owner and the land user are currently considered by V.V. Pechenkina form an imperfect triangle

We believe that under the sign of a "question" security should be considered, which is expressed in territorial integrity, food security, social protection of the indigenous population, taking into account the conservation of natural capital. 


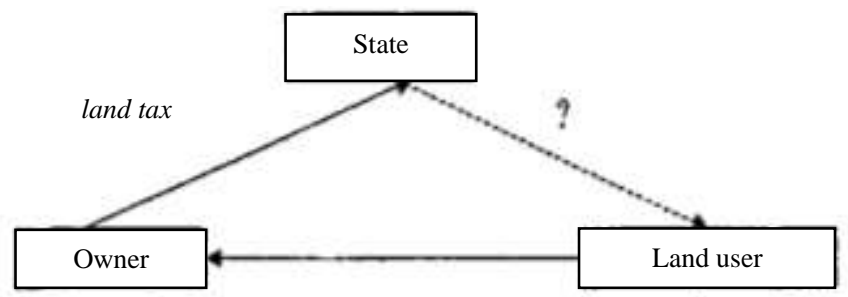

rent

Fig. 1. Economic relations regarding land use
Among foreign experts considering industry-specific features of accounting in agriculture, it should be noted: $\mathrm{T}$. Arens, A. Barrett, T. Grotto, K. Luca, R. Anthony, G. Muller, G. Milk, B. Needles, etc.

Features of accounting in agricultural organizations are given in the table 2 .

The main means of production in agriculture is land; the period of production does not coincide with the period of receipt of finished products, which affects the organization of accounting, the system of internal control of land resources.

TABLE II. FEATURES OF ACCOUNTING IN AGRICULTURAL ORGANIZATIONS

\begin{tabular}{|c|c|}
\hline Author & Highlighted Features \\
\hline $\begin{array}{l}\text { E.G. Lysenko } \\
\text { Yu.I. Agirbov, } \\
\text { N. A. Serova }\end{array}$ & $\begin{array}{l}\text { These scientists distinguish the following features of the agricultural sector: } \\
\text { 1. The influence of climatic conditions on the level of production, as well as the dependence of production on the biological characteristics of } \\
\text { the resources used. } \\
\text { 2. Low quality and a small amount of resources (materials, fertilizers) makes the yield dependent on weather conditions. } \\
\text { 3. Reduction of income, adverse change in the ratio of supply and demand in the market. } \\
\text { 4. The influence of seasonality factor on the production process. } \\
\text { 5. The decrease in efficiency is associated with a change in the state economic policy in the field of agricultural production }\end{array}$ \\
\hline Ivasenko A.G. & $\begin{array}{l}\text { 1. "Resources are land and biological factors are plants and animals. } \\
\text { Production processes are closely intertwined with biological, the results of which are greatly influenced by weather and climate conditions. } \\
\text { 2. The production of various crop and livestock products using technological processes of various lengths of time, production costs are carried } \\
\text { out in the present, and income is obtained in the future. } \\
\text { 3. Consumable fixed assets (except for working and productive livestock and perennial plantings) are not reproduced in agriculture, but only } \\
\text { in industrial enterprises (machinery and equipment) }\end{array}$ \\
\hline Piesengolz M.Z. & $\begin{array}{l}\text { Features of accounting in agriculture: } \\
\text { 1. The main means of production is land, and in this regard, account should be taken of land and its costs. } \\
\text { 2. Accounting should be designed in such a way as to provide analytical accounting of the number of animals. } \\
\text { 3. Agricultural production is carried out on large areas. } \\
\text { 4. Accounting for production costs should be organized in accordance with production cycles. } \\
\text { 5. "The biological characteristics of agricultural plants and animals are related to the fact that several types of products are obtained from one } \\
\text { crop or type of livestock. } \\
\text { 6. The receipt of the finished product is timed to coincide with the maturity of plants and animal rearing. } \\
\text { 7. Part of the products of own production in agriculture goes into domestic circulation. } \\
\text { 8. Due to the influence of natural climatic factors in agriculture, especially in crop production, significant seasonality still remains. }\end{array}$ \\
\hline Lisovich G.M. & $\begin{array}{l}\text { Features of accounting in agriculture: } \\
\text { 1. The working period does not coincide with the production process. } \\
\text { 2. Agricultural enterprises independently for their own production reproduce part of the means of production they need. } \\
\text { 3. The seasonality factor has a direct impact on the agricultural sector. } \\
\text { 4. An industry feature is that several types of products are obtained from one culture or animal species. } \\
\text { 5. The bulk of agricultural products goes into domestic circulation. } \\
\text { 6. During the year, agricultural products accounted for at the planned cost, and after the preparation of accounting estimates for the year, the } \\
\text { cost is adjusted to the actual cost at the end. } \\
\text { 7. Agricultural production is carried out on large areas; agricultural machines are used. } \\
\text { 8. Finished products are produced during the period of plant maturation and animal rearing. } \\
\text { 9. Organization of analytical accounting of livestock. } \\
\text { 10. The presence of various forms of ownership of agricultural enterprises (cooperatives, unitary enterprises and associations, partnerships, } \\
\text { farms, etc.). } \\
\text { 11. Land is the main means of production, in this regard, it is important to ensure accurate accounting of land and investments" }\end{array}$ \\
\hline
\end{tabular}

The formation of reliable, complete, relevant information on the state of the company's activity on the basis of the use of accounting and unlearned data is necessary for successful activity management.

Professor V.F. Paly believed that subelements should be distinguished from each element of financial reporting, as well as grouping indicators into groups and subgroups in order to present more detailed, truthful and transparent information in the reporting.

Agricultural organizations for 2019 compile reports in accordance with Order No. 669 of the Ministry of Agriculture of Russia dated 03.12.2019 “On approval of the report forms for 2019" (registered with the Ministry of Justice of Russia on January 29, 2020), which includes [2]:

- balance sheet (land assets- agricultural land not allocated);

- report on financial results (the result from the sale of agricultural land is not highlighted);

- report on changes in capital (increase / decrease in capital due to the organization of agricultural activity on agricultural lands is not withdrawn);

- cash flow statement (payments from the sale of land assets are not allocated); 
- explanations to the balance sheet and the report on financial results (no movement of agricultural land, rights to agricultural land allocated, no interdependence of land conservation and receipt of subsidies);

- report on the number and wages of agricultural workers the price of 1 ha of land should contain the cost of reproduction of labor resources;

- report on industry performance indicators of organizations of the agro-industrial complex management structure, land assets are unclear; land assets are not allocated in leased fixed assets, other income / expenses do not reflect transactions with land, names of farms included in the holding, their main indicators are not reflected

- report on the costs of the main production - there are no costs associated with maintaining the fertility of agricultural land;

- report on the production, costs, costs and sales of crop products - there is no information on land by lease term, land conservation costs, balance of movement of land assets, purchase / sale price of 1 ha; information on buyers of land assets; nutrient removal balance; territorial aspect of activity

- report on the means of earmarked funding - the lack of interconnection between earmarked financing and conservation of natural resources;

- report on production capacity - there is no indicator the planned volume of production of organic fertilizers;

- report on the costs of performing work and the provision of services (on the side) - fertility restoration services;

- report on the production, costs, costs and sales of livestock products - there is no movement for organic fertilizers:

- report on the production, costs, costs and sales of primary and industrial processing products made from agricultural raw materials - there is no information on the issue of products per share;

- report on the availability of animals - must be taken into account when subsidizing production (organic fertilizers increase the level of land fertility);

- balance of products - reflect payment by shares, depending on the term of the lease of land;

- report on agricultural machinery and energy - add technological maps of 2-3 main crops with a balance of nutrient removal.

Based on the data presented on the company's websites, we received the following information for each of them.

For Miratorg, the site contains information for the 1 st half of 2018 under IFRS. From the brief overview it is clear that the Agromir Limited company, the Republic of CYPRUS, is subordinate. In 2016, Gf Essets Management LLC acted as the balance holder of land. In 2018, it was not among the main companies of the Group, although as of March 31, 2016 the carrying value of the land asset amounted to 896 million rubles and as of June 30, 2018 already 5440 thousand rubles. In the balance sheet of the agricultural holding, land resources are not allocated as a separate line, but there are biological assets. Information on land acquisition is highlighted on the website:

- area of 1 ha and location of the region: Belgorod, Bryansk, Kaliningrad, Kaluga, Kursk, Oryol, Tula

- purchase takes into account the location, quality, presence / absence of processing, proximity to the land of the company

- land plots of arable land and pastures with an area of 500 hectares are in priority.

- calculation and sale of the share is made immediately on the spot, in cash, and if the land is allocated, then based on the wishes of the owner of the land [3].

If TC Miratorg has a link to the disclosure of information on its page, then Prodimeks doesn't.

The information content of the Prodimeks website gives the following information: a land bank - more than 800 thousand hectares and 2 sugar factories 2 are located in the Kursk region - Kursksakharprom LLC - Zolotukhinsky branch and Lyubimovsky branch - Bolshesoldatsky district Eight plants are located in the Voronezh region, one each in the Krasnodar Territory, Stavropol Territory, Penza Region, the Republic of Bashkortostan, and 2 plants in the Belgorod Region. Thus, the land bank is concentrated in these regions.

The main activities of the Group at LLC UK Agrokultura are crop production and animal husbandry. In the Kursk region, the holding operates in the Dmitrov, Khomutovsky, Zheleznogorsk, Rylsky, Konyshevsky districts. The site contains information on a special assessment of working conditions, from which it is clear that the full-time unit of the agronomic department is an agronomist-agrochemist-soil specialist; accounting includes 4 accountants: for the accounting of fixed assets and lease obligations, for accountable persons and settlements with shareholders, for settlements with suppliers and buyers, for wages. There are two deputy chief accountants, one for production accounting and one for tax accounting, the chief accountant; there is also an accounting automation department with $1 \mathrm{C}$ programmers, the corporate reporting and planning department is represented by the chief economist, in addition there is an internal control and treasury service. Land relations are regulated in the holding by the legal department (legal adviser on land issues, specialist in land issues, analyst on land issues) [4]. LLC UK Agrokultura declares that due to moisture and resource saving technologies, subsurface and minimal soil cultivation, development of land reclamation, soil fertility is restored and developed. The main success factors, as the group states, are effective management of the activities of subsidiaries in the field of agriculture, financial accounting, financing of investments in fixed assets, etc. Financial statements of UK Agrokultura LLC are not available on the company's website. 
Rusagro's website is more informative in terms of obtaining information: the company is owned by ROS AGRO PLC - the Republic of CYPRUS, there is quantitative information about the land bank for 2018, as well as by region. In the Kursk region - 27 thousand hectares of land (5\%) and 2 sugar factories - OJSC "Krivets-Sahar" and JSC "Kshensky sugar factory"; in the Belgorod region 303 thousand hectares or $46 \%$ of the total arable land of the company, in Tambov 184 thousand hectares (26\%), Primorsky Krai $-14 \%$ of land, Oryol region $-7 \%$, Voronezh region $-2 \%$.). $39 \%$ of all capacities of sugar factories are located in the Tambov region, in the Belgorod region $-30 \%$, in the Kursk region $-20 \%$, the Oryol region $-10 \%$. In the Kursk region LLC Kshenagro operates from 5 districts of 27.427 ha - arable land of 26.890 ha. The company's land asset is $90 \%$ arable land. Partially, investments are directed to digitalization and automation in order to improve the efficiency of field management (there is a digital transformation of the crop division). In 2018, the legal structure of the land bank was $51 \%$ - own lands, $42 \%$ - longterm leases and $7 \%$ short-term leases. There is a gradual transformation from rental to owner. Rusagro came to the lands of another holding company Razgulay. It is characteristic that the organization actually operates with a land asset -38 thousand hectares have retired land unsuitable for cultivation. Maybe one should engage in agricultural production in accordance with the recommended farming system, and not just from a business point of view? The company implements IT projects: targeted planning of production technologies (optimal crop rotation for each field), management and scheduling of production (100\% control of field work no later than the next day), management and scheduling of logistics (accounting, control, movement of costly inventories using bar coding and reflection in SAP ERP). If we consider the structure of sown areas, then $29 \%$ is wheat, soybean $24 \%$, sugar beets - $15 \%$, barley - $10 \%$, corn $-5 \%$, sunflower $-4 \%$, steam $-4 \%$ and other crops $9 \%$. That is, the structure of the sown area is exclusively for commodity production. Land assets in the holding's balance sheet are also not allocated, but $30 \%$ of assets are fixed assets, and $24 \%$ of assets as of December 31, 2018 are long-term investments (with a view to resale, possibly land). The balance sheet identifies long-term biological assets. From the annual report it also follows that the company seeks to maintain a favorable environment through the rational use of natural resources - both those involved in production and those located in the regions of the company. As measures to combat degradation, the organization carries out activities such as following crop rotation in crop rotation and soil deoxidation by introducing defecate on land in the coastal region. The organization adheres to the principles of rational use of a complex of mineral fertilizers - fertilizer standards are adapted to the specific content of nutrients in a particular field. Manure is also exported to agricultural land as fertilizer.

As of January 1, 2018, Rusagro's land assets amounted to 7.638.981 thousand rubles, 452.531 thousand rubles were received during the year, 4,810 thousand rubles were acquired in the framework of business combination transactions, and 139737 thousand rubles were disposed of, at the end of the year amounted to 7956685 thousand rubles.
As at December 31, 2019, the Group entered into 970 land lease agreements (12/31/2017 - 906 plots). Of these, 558 $(12 / 31 / 2017$ - 522) are fixed arenas in Russian rubles, and in 412 land lease agreements (12/31/2017 - 384) leases are established as non-monetary measures (agricultural products). In 2018, the corresponding rental expenses amounted to 408,287 rubles ( 2017 - 348.243 rubles), i.e. the rent under 1 contract in 2018 amounted to 990 rubles, and in 2017 907 rubles.

Land lease rights are recognized in intangible assets. The useful life of this intangible asset is $2-50$ years, amortized on a straight-line basis. Characteristically, on September 19, 2018, the group acquired a $100 \%$ ownership interest in Vozrozhdenie LLC, which has 11 thousand hectares of land in the Tambov Region. The transaction amount amounted to 217.850 thousand rubles, that is, 1 ha of black soil was purchased for 19805 rubles. At the time of the acquisition, production was not conducted at the production enterprise; the acquisition was with the aim of gaining control of agricultural land. All assets except land were immaterial (as indicated on the site) [5].

After analyzing the Rusagro website, you can compare the information and draw the appropriate conclusions, as there is something to analyze.

The price of an agricultural hectare in the central federal district is almost three times lower than in the Krasnodar Territory.

For Agrocomplex, a careful attitude to nature and its conservation have become fundamental concepts of the activities of the entire agricultural holding. Land assets were not allocated in the balance sheet, but vineyards (perennial plantings) are shown separately in the explanatory notes to the balance sheet and in the statement of financial results; among other types of fixed assets, land plots and nature management objects and capital investments for radical land improvement are shown. State aid is used to compensate for current expenses on crop production, but the state of the land is not taken into account. No more information is provided on the site.

EkoNiva-AIC operates in the Voronezh, Kursk, Novosibirsk, Kaluga, Ryazan, Moscow, Tyumen, Orenburg, Leningrad regions, the republics of Tatarstan and Bashkortostan, the Altai Territory on an area of more than 599.000 ha (as of 01/09/2020). In the Kursk region, "Economics-AIC" is represented in the Shchigrovsky, Solntsevsky, Belovsky regions - on an area of 45.500 ha. All products of the holding are certified according to the EC834 / 2007 standard. The head of the holding is a German citizen, but since 2013 is already a citizen of Russia.

In 2005, the purchase price of agricultural land in Germany averaged 8692 euros per hectare, in 2018 the buyer had to pay an average of $\mathbf{2 5} \mathbf{4 8 5}$ euros per hectare - an increase of 193 percent.

That is, the price of 1 ha of German land is 90 times more than 1 ha of chernozem in Russia. 
Prices for rental space in Germany have risen sharply in recent years. More than half of Germany's agricultural land belongs to non-farmers. There should be transparency in the land market. BMEL (Federal Ministry of Food and Agriculture), when purchasing land since 2020, makes a distinction between farmers and non-farmers in Germany. The average area in Germany is about 70 hectares, some holdings manage 5,000, 10,000 or even 20,000 hectares [6]. In order to reform the Common European Agricultural Policy, BMEL is studying how to significantly reduce payments to business groups and holding companies. In 2016, ten percent of enterprises worked environmentally. The share of organically cultivated areas in the field of agriculture in 2016 amounted to 7.5 percent. Income in German agricultural organizations is defined as "profit plus personnel costs" [7].

Agricultural organizations should increase the efficiency of their business activities in order to achieve sustainable development [10, 13, 14].

Modern agricultural policy is formed by lobbyists of large agricultural holdings. Given the limited supply and demand for land, state support should be provided to rational land users, preserving soil fertility. Land management should ensure the balanced development of the economy and improve the environment through sustainable, rational and environmentally sound land use $[11,12]$

Monopolistic companies increase their capital thanks to new products and technologies, innovations and the program, and often use minimal initial funds, which is a characteristic feature of the digital economy. The growing volume of information requires its processing in real time, the use of organic farming systems in order to prevent threats to the national security of states

The aim of agricultural policy should be to align social needs with agricultural practice $[8,9]$. It is not necessary to take out nutrients more than is introduced. Organic farming should be guided by the above principle.

Promotion of land conservation can be supported through compensation for the costs incurred by organizations as a result of compliance with additional production rules. Existing rules do not include such costs as the costs of environmental degradation in the economic activities of agricultural producers.

\section{CONCLUSION}

Most accounting systems are not adapted to support highspeed decision making. In this regard, one cannot disagree with the opinion of Y.V. Sokolov that "traditional accounting, focused on specific industries, has outlived itself." In particular, there is a need for financial reporting that combines environmental and economic analyticity and efficiency. The work compares the specialized reporting of the largest agricultural holdings in Russia from free sources of information and proposes to supplement the reporting structure with indicators, namely, highlight "Land assets" in the balance sheet, propose a report "Land assets", which reflects the purchase price of 1 ha, the balance of movement of land assets with specific sellers, reflect the balance of nutrient removal, indicate the terms of conclusion of leases for land assets, make information on accounting (final owl) reporting available on the website of agricultural holdings, as well as to identify it on the site Russian Ministry of Agriculture, government support, preferential loans should be rendered rational land users, preserving soil fertility.

\section{References}

[1] I.P. Valueva, E.A. Novoselov, "Rating of the largest owners of agricultural land in Russia for 2019”, Econ., Labor, Manag. in Agricult., vol. 5 , no. 50, p. 99, 2019.

[2] Reporting on the financial and economic condition of producers of agroindustrial complex. Retrieved from: http://cspapk.ru/otchetnost/

[3] Miratorg: purchase of land. Retrieved from: https://miratorg.ru/servicesfor-business/purchase/\#

kakim_obrazom_proiskhodit_raschet_s_prodavtsami_zemelnykh_aktivov

[4] Agriculture. Retrieved from: http://agrokulturarussia.com/doc/ \%D0 $\% \mathrm{~A} 1 \% \mathrm{D} 0 \% \mathrm{~B} 2 \% \mathrm{D} 0 \% \mathrm{BE} \% \mathrm{D} 0 \% \mathrm{~B} 4 \% \mathrm{D} 0 \% \mathrm{BD} \% \mathrm{D} 0 \% \mathrm{~B} 0 \% \mathrm{D} 1$ $\% 8 \mathrm{~F} \% 20 \% \mathrm{D} 0 \% \mathrm{~B} 2 \% \mathrm{D0} \% \mathrm{~B} 5 \% \mathrm{D} 0 \% \mathrm{~B} 4 \% \mathrm{D} 0 \% \mathrm{BE} \% \mathrm{D0} \% \mathrm{BC}$ $\% \mathrm{D} 0 \% \mathrm{BE} \% \mathrm{D} 1 \% 81 \% \mathrm{D} 1 \% 82 \% \mathrm{D} 1 \% 8 \mathrm{C} \% 20 \% \mathrm{D} 0 \% \mathrm{~A} 1 \% \mathrm{D} 0 \% 9 \mathrm{E}$ $\% \mathrm{D} 0 \% \mathrm{~A} 3 \% \mathrm{D} 0 \% \mathrm{~A} 2 . \mathrm{PDF}$

[5] Rusagro: Presentations. Retrieved from: https://www.rusagrogroup.ru/ ru/investoram/otchety-i-publikacii/prezentacii/

[6] Land use market of the earth. Retrieved from: https://www.bmel.de/DE/ Laendliche-Raeume/04_Flaechennutzung/_texte/ LandwirtschaftlicherBodenmarktinDeutschland.html?nn=2844614

[7] Statistics. Retrieved from: https://www.bmel.de/DE/Service/Statistik/ _Texte/WirtschaftlicheLage.html

[8] Agriculture. Retrieved from: https://www.bmel.de/DE/Landwirtschaft/ _Texte/Agrarbericht2019.html

[9] Agricultural tables. Retrieved from: https://www.bmelstatistik.de/landwirtschaft/tabellen-zur-landwirtschaft/

[10] T. Bobovnikova, T. Vorozheykina, "Accounting for the fertility of land resources as a factor in the sustainable development of the Kursk region", IOP Conf. Ser. Earth and Environmental Sci., vol. 395, no. 1, p. $012029,2019$.

[11] G.S. Merzlikina, "Economic efficiency of "ecological health" of the region", Proc. of the Voronezh State Univer. of Engineer. Technol., vol. 81, no. 2, pp. 312-319, 2019. Retrieved from: https://doi.org/10.20914/2310-1202-2019-2-312-319

[12] A.I. Khorev, E.V. Gorkovenko, I.V. Platonova, "Economic security of the Central Black Earth region: assessment of the state and threats", Proc. of the Voronezh State Univers. of Engineer. Technol., vol. 80, no. 3, pp. 368-376, 2018. Retrieved from: https://doi.org/10.20914/2310-1202-2018-3-368-376

[13] T. Skryl, V. Osipov, T. Vorozheikina, "On the way to ecological agriculture: Decision-making process in agrarian state policy", IOP Conf. Ser. Earth and Environmental Sci., vol. 274, no. 1, p. 012066, 2019.

[14] D.S. Strebkov, "Advanced tendencies in development of photovoltaic cells for power engineering", Thermal Engineer. (English translation of Teploenergetika), vol. 62, no. 1, pp. 7-13, 2015. 